\title{
A New Approach to the Synthesis of Optically Active Norephedrine, Norpseudoephedrine and Cathinone via Double Asymmetric Induction
}

\author{
Dong Jun Kim and Byung Tae Cho* \\ Department of Chemistry: Hallym University, Chunchon, Gangwondo 200-702, Korea \\ Recened August 18, 2003
}

\begin{abstract}
New and facile synthetic routes for preparation of oplically aclive norephedrine, norpseudoephedrine and cathinone with high optical purties via double asymmetric induction by employing asymmetric reduction of 2-N-protected amino (or azido)-I-phenylpropanone and 2-methanesullonyloxy-1-phenylpropanone with CBScatalyzed-borane and " $\mathrm{L} \mathrm{p}_{2} \mathrm{BCl}$ as chiral reducing agents are described.
\end{abstract}

Key Words : Asymmetric reduction, Norephedrine, Norpsedorephedrine, Cathinone

\section{Introduction}

Optically active norephedrine $\mathbf{1}$, norpseudoephedrine $\mathbf{2}$ and cathinone 3 are naturally occurring alkaloids possessing amphetamine-like pharmacological activity which are used as anorexic drugs (figure 1). Among those, $\mathbf{1}$ and $\mathbf{2}$ are of great importance as chiral auxiliaries, ligands, bases and catalysts in a variety of asymmetric reaction, 1,2 such as enolate alkylation, ${ }^{\text {in }}$ aldol reaction, ${ }^{\text {ib-d }} \alpha$ or $\beta$-amino acid synthesis, ${ }^{\text {icog }}$ rearrangement of epoxides to allylic alcohols, ${ }^{\text {it }}$.j oxazaborolidine reduction, ${ }^{\text {ik }}$ hydrogen transfer reaction, ${ }^{3 /-m}$ and alkynylation to aldehydes. ${ }^{\text {n-p }}$ Moreover, these compounds are widely used as very useful starting materials for preparation of chiral 2-oxazoline. " piperidines. ${ }^{5}$ aziridines, and imidazolines. ${ }^{7}$ Accordingly, the development of a simple and convenient synthetic methods for these compounds is of great interest. For the synthesis of these compounds, a number of methods including optical resolution of racemic mixtures, ${ }^{8}$ bioreduction of 2-azido-1-phenylpropanone," regioselective azidolysis of chiral cis- $\beta$-methylstyrene oxides. ${ }^{10}$ diastereoselective reduction of chiral 2-hydroxyamino-1phenylpropanone $^{\text {ll }}$ or 1-hydroxy-1-phenyl-2-propanone-2()-methyloxime. ${ }^{12}$ diastereoselective phenylation of $\mathrm{N}$-protected alaninal derivatives, ${ }^{1.3}$ and diastereoselective methylation of chiral $O$-protected cyanohydrin ${ }^{14}$ or $\alpha$-hydroxy aldehyde hydrazones ${ }^{15}$ have been presented. However, these methods

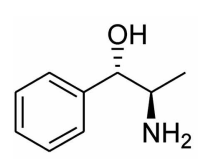

$(1 S, 2 R)-1$<smiles>C[C@H](N)C(O)c1ccccc1</smiles>

$(1 R, 2 S)-1$<smiles>C[C@H](N)[C@H](O)c1ccccc1</smiles><smiles>[AsH3]</smiles><smiles>CC(N)C(O)c1ccccc1</smiles>

$(1 R, 2 R)-2$

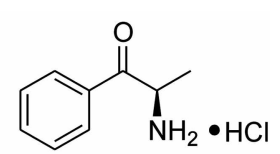

$(R)-3$

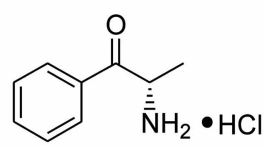

(S)-3
Figure 1

Corresponding author. e-mail: btcho@ọhallym.ac.kr except for resolution of racemic mixture and bioreduction of 2-azido-I-phenylpropanone need mostly chiral substrates as starting materials. Recently a number of highly efficient asymmetric reductions of prochiral ketones using catalytic and stoichiometric chiral reducing agents to give high enantioselectivity have been reported. ${ }^{16}$ of such chiral reducing agents, it has been realized that CBS-oxazaborolidine-catalyzed borane and (-)-B-chlorodiisopinocampheylborane ("I $I \mathrm{pc}_{2} \mathrm{BCl}$ ) are highly effective for asymmetric reduction of various $\alpha$-functionalized ketones, leading to the corresponding alcohols with high enantioselectivity. ${ }^{17}$ It was expected that asymmetric reductions of $2-N$-protected amino (or azido)-]-phenylpropanone using these reducing agents and the same reductions of 2-methanesulfonyloxy-1-phenylpropanone followed by $S, 2$ type amination might be one of the most convenient methods for preparation of optically active 1-3, if the double asymmetric inductions ${ }^{18}$ and/or kinetic resolutions are included in these reductions. However, to our knowledge, there have been no reports of such reductions. We report here new and facile synthetic routes for the preparation of chiral 1-3 using this methodology.

\section{Results and Discussion}

The synthetic routes of 1-3 are outlined in Scheme I. First we studied the enantioselective synthesis of 1-3 via asymmetric reductions of 2-N-Boc and $\mathrm{N}$-Cbz-amino-1-phenylpropanone (7a and $7 \mathbf{b}$ ) with $(S)$-MeCBS-oxazaborolidinecatalyzed borane (CBS-reagent) (route I). Thus the reduction was carried out by slow addition of $N$-protected amino ketones 7 over $1.5 \mathrm{~h}$ to a solution of 1.0 equiv. $(3.0$ equiv, as hydride) of the reagent 5 in the presence of 0.1 equiv of 4 in [HH at $25^{\circ} \mathrm{C}$ (method A). As shown in lable 1 , the reduction of 7a afforded a $60: 40$ diastereomeric mixture of product alcohols, the anti isomer (8a + ent-8a) and the sin isomer $\left(9 \mathbf{a}+e^{n} t-9 \mathrm{a}\right)$, in $96 \%$ yield within $10 \mathrm{~min}$ (entry 2 ). In the case of $7 \mathbf{b}$, the ratio was $65: 35$ (entry 4 ). The diastereomeric ratios of products alcohols ( 8 and 9) were determined by HPLC analysis using a $25 \mathrm{~cm}$ Whelk-O1 chiral column. With respect to enantioselectivies, the reductions provided $\mathbf{8 a}$ with $48 \%$ ee, 9 a with $70 \%$ ee, 8 b with 


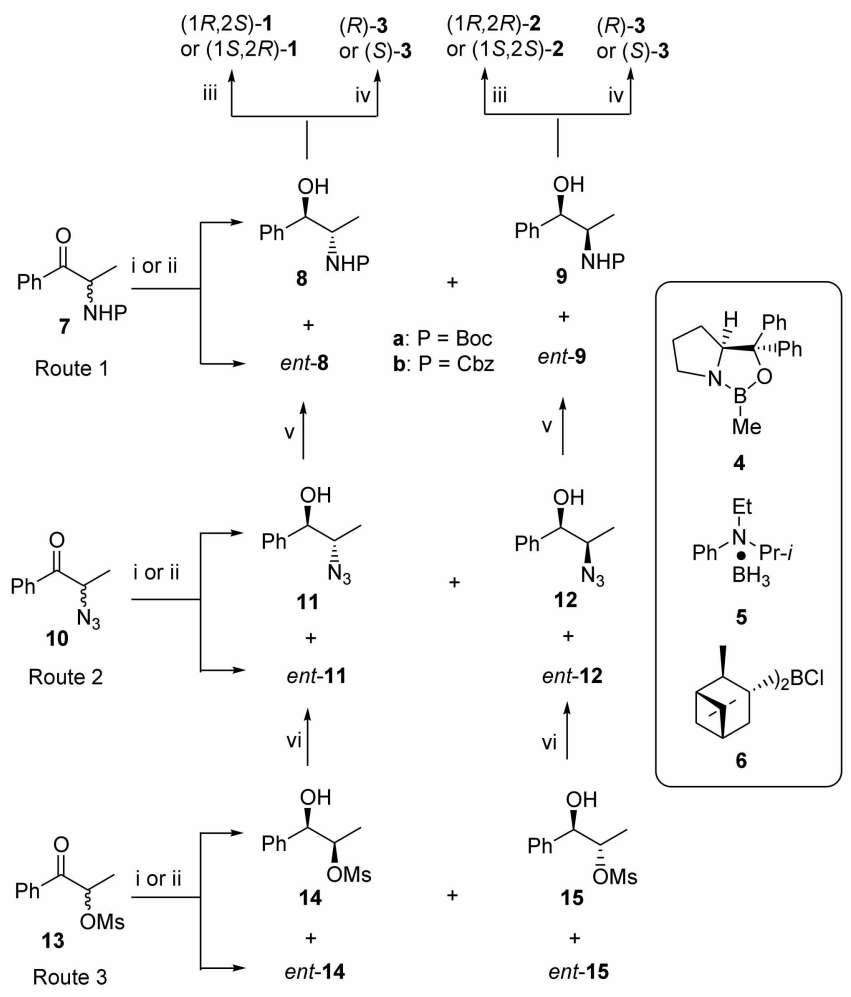

Scheme 1. Reaction conditions: i. $4(0.1 \mathrm{eq}) .5(1.0 \mathrm{eq})$. THF. $25^{\circ} \mathrm{C}$ (Method A), ii, 6 (1.2 eq), Tlil: $0^{\circ} \mathrm{C}$ (Method 13), iii, For 8a and

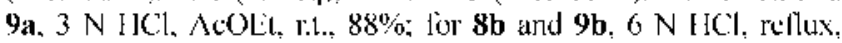
$89 \%$. iv. $\mathrm{PCC}\left(1.5\right.$ eq). $\mathrm{CH}_{2} \mathrm{Cl}_{2}$, r.t. then $3 \mathrm{~N}$ or $6 \mathrm{~N} \mathrm{HCl.} 74-76 \%$ v.

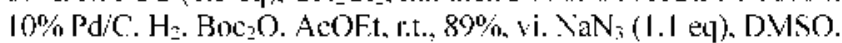
$80^{\circ} \mathrm{C} .82 \%$

$26 \%$ ee and 9 b with $55 \%$ ee, which, were easily separated by a flash column chromatography on silica gel. $N$-Boc and $N$ -
Cbz groups of 8 and 9 were deprotected with $3 \mathrm{~N} \mathrm{HCl}$ solution at room temperature and $6 \mathrm{~N} \mathrm{HCl}$ solution under reflux condition, respectively. ${ }^{19}$ Subsequently the reaction mixtures were basified with $6 \mathrm{~N} \mathrm{NaOH}$ and extracted with dichloromethane to give norephedrine $\mathbf{1}$ and norpseudoephedrine 2. Using this procedure, we obtained $(\mathrm{I} R, 2 S)$ - I with $48 \%$ ee from $8 \mathbf{a}$ and $(1 R, 2 R)-2$ with $70 \%$ ee from $9 \mathbf{a}$ in $88-$ $90 \%$ yields. When 9 a with $70 \%$ ee was oxidized with $P C C$. in dichloromethane at room temperature, followed by deprotection with hydrochloric acid. $(R)$-cathinone 3 with $70 \%$ ee was produced in $80 \%$ yields. ${ }^{{ }^{*}+}$ Comparing optical rotation values for optically active $\mathbf{1}, 2$ and 3 reported with those obtained, we found that no racemization occurs in the course of deprotection and oxidation. On the other hand, the same reductions of 2-azido-I-phenylpropanone $\mathbf{1 0}$ (route 2) and 2-methanesulfonyloxy-1-phenylpropanone $\mathbf{1 3}$ using CBS reagent (route 3 ) provided inseparable diasteromeric mixtures of azido alcohols (11 and 12) and 1,2-diol monomesylates (15 and 14). To separate the diastereomeric mixtures and to determine their ratios and enantioselectivities, the product alcohols were converted into $8 \mathbf{a}$ (or ent-8a) and 9a (or ent-9a) in the following manners. The azido alcohols 11 and 12 obtained were hydrogenated on $10 \% \mathrm{Pd} / \mathrm{C}$ under atmospheric pressure in the presence of excess $\mathrm{Boc}_{2} \mathrm{O}$ in ethyl acetate at room temperature. The product alcohols 15 and $\mathbf{1 4}$ produced from route 3 were converted into $8 \mathbf{a}$ (or ent-8a) and 9a (or ent-9a) by the $S_{k} 2$ type reaction with sodium azide in DMSO at $80^{\circ} \mathrm{C}$, followed by catalytic hydrogenation in the presence of excess $\mathrm{Boc}_{2} \mathrm{O}$ as described above. HPLC analysis of the $N$-Boc amino alcohols obtained from route 2 and 3 showed the formation of ent-8a with $76 \%$ ee from ent-11, ent-9a with $26 \%$ ee from ent-12, ent-8a with

Table 1. Fnantioselective synthesis of 1-3 via asymmetric reduction using method $A^{\prime \prime}$

\begin{tabular}{|c|c|c|c|c|c|c|c|c|c|}
\hline \multirow{2}{*}{ Entry } & \multirow{2}{*}{ Cpd } & \multirow{2}{*}{$\begin{array}{l}\text { Method } \\
\text { (cpd:5) }\end{array}$} & \multirow{2}{*}{$\begin{array}{l}\text { Yicld }{ }^{\prime \prime} \\
(\%)\end{array}$} & \multicolumn{4}{|c|}{ Ratio $(\%)$} & \multicolumn{2}{|c|}{ Products. $\% \mathrm{ee}^{\mathrm{cid}}$} \\
\hline & & & & \multicolumn{2}{|c|}{ anti } & \multicolumn{2}{|c|}{ syn } & \multirow{2}{*}{$\frac{1 \text { and } 2}{(1 / R .2 S)-1.74}$} & \multirow{2}{*}{$\frac{\text { ketones }}{(k)-7 \mathbf{a}^{\prime} 27(26)^{2}}$} \\
\hline 1 & $7 a$ & A & 40 & $8 a$ & 64 & $9 a$ & 20 & & \\
\hline & & $(1: 0.17)$ & & $e n t-8 \mathbf{a}$ & 10 & $e n t-9 \mathbf{a}$ & 6 & $(1 R .2 R)-2.54$ & \\
\hline \multirow[t]{2}{*}{2} & $7 a$ & A & 96 & $8 \mathbf{a}$ & $44(46)^{\prime}$ & $9 a$ & $34(33)$ & $(I R .2 S)-1.48$ & \\
\hline & & $(1: 1)$ & & $e n t-8 \mathbf{a}$ & $16(17)$ & $e n t-9 \mathrm{a}$ & $6(4)$ & $(1 R .2 R)-2.70$ & $(R)-\mathbf{3 .} 70$ \\
\hline \multirow[t]{2}{*}{3} & $7 b$ & $\Lambda$ & 45 & $\mathbf{8 b}$ & 57 & $9 b$ & 19 & $(I R .2 S)-1.60$ & $(R)-7 \mathbf{b}]^{\prime} 26(26)$ \\
\hline & & $(1: 0.17)$ & & $e n t-8 \mathbf{b}$ & 15 & $e n t-9 b$ & 9 & $(I R .2 R)-2.36$ & \\
\hline \multirow[t]{2}{*}{4} & $7 b$ & $\Lambda$ & 95 & $\mathbf{8 b}$ & $4 \mathrm{I}(43)^{\prime}$ & $9 b$ & $27(28)$ & $(I R .2 S)-1.26$ & \\
\hline & & $(1: 1)$ & & ent-8b & $24(22)$ & ent-9h & $8(7)$ & $(1 R .2 R)-2.55$ & \\
\hline \multirow[t]{2}{*}{5} & 10 & $A$ & 43 & 11 & 10 & 12 & 19 & $(I S .2 R)-1.38$ & $(R)-10^{x} 18(14)^{\prime}$ \\
\hline & & $(1: 0.17)$ & & ent-11 & 22 & $e n t-12$ & 49 & $(1, S .25)-2.44$ & \\
\hline \multirow[t]{2}{*}{6} & 10 & $\mathrm{~A}$ & 97 & 11 & $5(8)^{i}$ & 12 & $24(23)$ & $(I S .2 R)-1.76$ & \\
\hline & & $(1: 1)$ & & ent-11 & $26(27)$ & $e n t-12$ & $45(42)$ & $(1 S .2 S)-2.26$ & \\
\hline \multirow[t]{2}{*}{7} & 13 & A & 40 & 15 & 6 & 14 & 20 & $(I S .2 R)-1.44$ & $(R)-13^{\prime \prime} 9(10)^{\prime}$ \\
\hline & & $(1: 0.17)$ & & ent- 15 & 22 & ent-14 & 52 & $(1 S .2 S)-2.57$ & \\
\hline \multirow[t]{2}{*}{8} & 13 & A & 98 & 15 & $3(5)^{r}$ & 14 & $25(24)$ & $(1 S .2 R)-1.30$ & \\
\hline & & $(1: 1)$ & & ent-15 & $26(26)$ & $e n t-14$ & $46(45)$ & $(1 S .2 S)-2.78$ & \\
\hline
\end{tabular}

"Method A: Reduction was carricd out with 1,0 or 0.17 equiv. of 5 in the presence of 0.1 equiv of 4 in THF at $25^{\circ} \mathrm{C}$. "Isolated y ields of diastercomeric mixtures. $\%$ Fes of 7.8 .9 and 13 were determined by HPI.C analysis using a $25 \mathrm{~cm}$ Whelk-( ) l chiral column. Using the same column. enantioselectivities of 10. 11. 12. 14 and 15 were deternined alter conversion of these compounds to 7a. 8a or 9a. ${ }^{2} \mathrm{Determined} \mathrm{by} \mathrm{comparison} \mathrm{with}$ their knowt] absolute conligurations and optical rolation values. ${ }^{5} 5 \%$ of unreacted ketone 7 a was recovered. ${ }^{7} 4 \%$ of unteacted ketone 7 b was recovered. $" 50 \%$ of unreacted ketone 10 was recovered. $54 \%$ of unreacted ketone 13 was recovered. The figures in parentheses indicated the values calculated from each of kinetic resolution data of the corresponding ketomes 7. 10 and 13. 'The' values calculated from diasteremeric ratios of the corresponding product alcohols. 


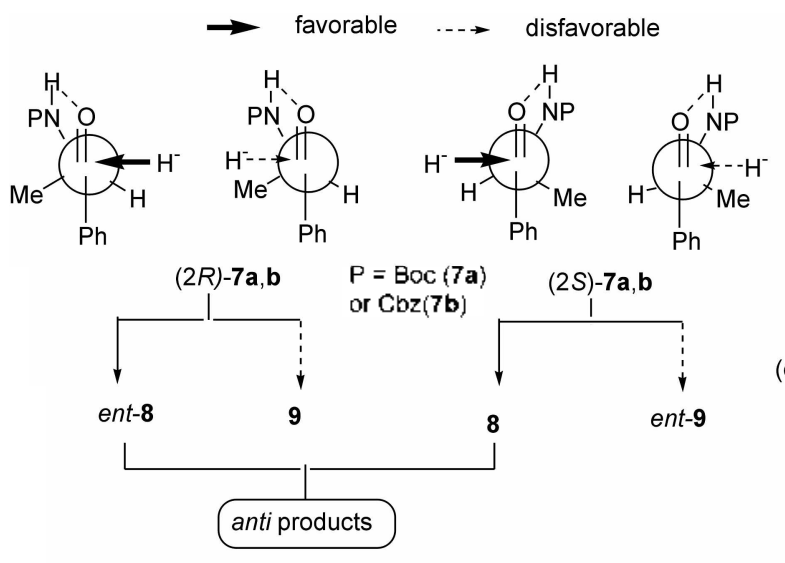

(eq 1)
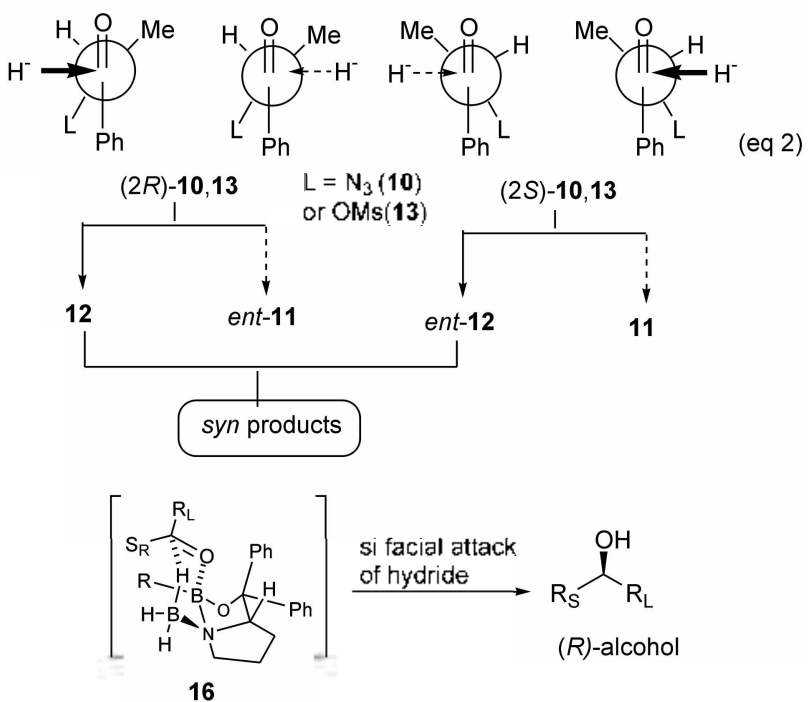

Scheme 2

$30 \%$ ee from cht-14 and ent-9a with $78 \%$ ee from ent-15. which could be converted into ( $1 S, 2 R)-1$ and $(1 S, 2 S)-2$ with no loss of enantiomeric purity, respectively (entries 6 and 8 ). To find out that these reductions were included with kinetic resolution or not, the same reductions of 7,10 , and 13 using 0.17 equiv. (0.5 equiv. as hydride) of the reagent 5 were carried out. The reduction of $7 \mathbf{a}$ and $7 \mathbf{b}$ afforded product alcohols, which were $8 \mathbf{a}$ with $74 \%$ ee and $\mathbf{9 a}$ with $54 \%$ ee in
$40 \%$ yield and $8 b$ with $60 \%$ ee and $9 b$ with $36 \%$ ee in $45 \%$ yield. The $a n t i / s y n$ rations of the product alcohols obtained were $74: 26$ for $7 \mathbf{a}$ and $72: 28$ for $7 \mathbf{b}$. From the reductions, (R)-7a with $27 \%$ ee and $47 \%$ yield and $(R)-7 \mathbf{b}$ with $26 \%$ ee in $53 \%$ yield were recovered (entries $\mathrm{l}$ and 3 ). The reduction of 10 under the same condition. followed by hydrogenation provided ent-8a with $38 \%$ ee and ent-9a with $44 \%$ ee in $43 \%$ yield with the unreacted ketone $(R)-10$ with $18 \%$ ee recovered in $50 \%$ yield (entry 5 ). In the case of 13 , ent-8a with $44 \%$ ee and ent-9a with $57 \%$ ee in $40 \%$ yield were obtained with recovery of the unreacted ketone $(R)-13$ with $9 \%$ ee in $54 \%$ yield (entry 7 ). In contrast to those of 7 , the reductions of 10 and 13 favorably afforded the syn products. as the anti/sin ratios were $32: 68$ and $28: 72$ for $\mathbf{1 0}$ and $\mathbf{1 3}$. respectively. Such different diastereoselectivities can be explained by Crams rule which predicts the steric outcome in the reduction of acyclic ketones having one asymmetric carbon atom adjacent to the carbonyl group..$^{20}$ According to this rule, distereoselectivities for 7 were controlled by the Cram-chelating model favoring the anti products (eq. 1 in Scheme 2), whereas the syn products for 10 and 13 were preferentially formed by the Cram open-chain model where hydride approaches electrophilic carbon from the side of the smallest substituent (hydrogen) when azide and mesyloxy groups occupy the largest substituent in transition state (eq 2). The Cram-chelating model for 7 can be rationalized by intramolecular hydrogen bonding between hydrogen of $N$ Boc or $\mathrm{Cbz}$ amide and the carbonyl. since such hydrogen bonding stabilizes their conformations in the transition states. With respect to enantioselectivity, it has been known that asymmetric induction by (S)-CBS-oxazaborolidinecatalyzed borane reduction (CBS reduction) of prochiral ketones comes from si facial attack of hydride on carbonyl of the ketone $\mathrm{R}_{\mathrm{L}} \mathrm{COR}_{\mathrm{S}}$ in the transition state $\mathbf{1 6}$ to produce $(R)$-alcohol. ${ }^{161}$ Interestingly, phenyl group behaves as the large group in the reduction of $\mathbf{1 0}$ and $\mathbf{1 3}$ in contrast to the same reduction of 7 , wherein the phenyl group behaved as the sinall group, although the reason is so far unclear. The values of enantiomeric excess of unreacted ketones recovered under the kinetic conditions are in good correspondences with those calculated from diasteromeric ratios of product alcohols obtained. Also, all the diastereomeric ratios of the

Table 2. Enantioselective synthesis of 1-3 via asymmetric reduction using method $\mathrm{B}^{\prime \prime}$

\begin{tabular}{|c|c|c|c|c|c|c|c|c|c|}
\hline \multirow{2}{*}{ Entry } & \multirow{2}{*}{ Cpd } & \multirow{2}{*}{$\begin{array}{l}\text { Method } \\
\text { (cpd:6) }\end{array}$} & \multirow{2}{*}{$\begin{array}{l}\text { Yield } \\
(\%)\end{array}$} & \multicolumn{4}{|c|}{ Ratio $(\%)$} & \multicolumn{2}{|c|}{ P'roducts. $\%$ eet } \\
\hline & & & & \multicolumn{2}{|c|}{ :nti } & \multicolumn{2}{|c|}{ דy's } & \multirow{3}{*}{$\begin{array}{c}1 \text { and } 2 \\
(1 R .2 S)-1.38 \\
(1 R .2 R)-2.89\end{array}$} & \multirow{3}{*}{$\frac{\text { ketones }}{(S)-7 a .)^{\prime} 31(30)^{\prime}}$} \\
\hline 1 & $7 a$ & B & 48 & $8 \mathbf{a}$ & 31 & $9 a$ & 52 & & \\
\hline & & $(1: 1.2)$ & & ent-8a & 14 & ent-9a & 3 & & \\
\hline \multirow[t]{2}{*}{2} & $7 \mathrm{~b}$ & B & 40 & $8 b$ & 30 & $9 \mathrm{~b}$ & 60 & (]$R .25)-1.58$ & $(5)-7 \mathrm{~b}: 19(18)^{\prime}$ \\
\hline & & $(1: 1.2)$ & & ent-8b & 8 & ent-9b & 2 & $(1 R .2 R)-2.93$ & $(R)-3.93$ \\
\hline \multirow[t]{2}{*}{3} & 10 & 13 & 60 & 11 & 17 & 12 & 64.7 & $(1 R 25)-1.96$ & $(5)-100^{k} 46(45)^{\prime}$ \\
\hline & & $(1: 1,2)$ & & ent-11 & 0.3 & $e n t-12$ & 18 & $(1 R, 2 R)-2,56$ & $(5)-3.96$ \\
\hline \multirow[t]{2}{*}{4} & 13 & 13 & 55 & 15 & 0 & 14 & 89 & $(1 R .25)-1.78$ & (5) $-13^{\prime \prime} 95(95)^{\prime}$ \\
\hline & & $(1: 1.2)$ & & $e n t-15$ & 0 & ent-14 & 11 & & \\
\hline
\end{tabular}

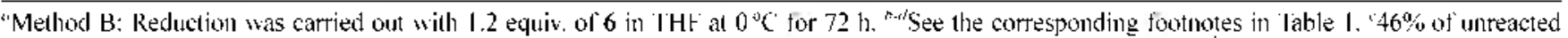
ketone 7 a was recovered. $52 \%$ of unteacted kutone $7 \mathrm{~b}$ was recovered. $33 \%$ of unnacted ketone 10 was recovered. "38\% of unreacted ketone 13 was recovered. 'The values calculated from diastereomeric ratios of the corresponding product aleohols. 
product alcohols obtained from route $\mathrm{I}-3$ using method $\mathrm{A}$ under non-kinetic conditions are good agreements with those calculated from the ratios obtained under kinetic conditions. From these results, we realized that the reductions by method A were included with double asymmetric induction via partial kinetic resolution.

Next, we examined synthesis of optically active 1-3 via asymmetric reduction of 7,10 and 13 with 1.2 equiv. of ${ }^{d} \mathrm{Jpc}_{2} \mathrm{BCl} 6$ in $\mathrm{THF}$ at $0{ }^{\circ} \mathrm{C}$ (method B). As shown in Table 2. all the reduction examined proceeded more slowly to afford the product alcohols in 40-60\% yields after $72 \mathrm{~h}$. Unreacted ketones were recovered in $33-52 \%$ yields. With respect to enantioselectivity, the reduction of 7 provided $8 \mathbf{a}$ with $38 \%$ ee, $9 \mathbf{a}$ with $89 \%$ ee. $8 \mathbf{b}$ with $58 \%$ ee and $9 \mathbf{b}$ with $93 \%$ ee. Enantiomeric purities of unreacted ketones recovered are $31 \%$ ee for $7 \mathrm{a}$ and $19 \%$ ee for $7 \mathrm{~b}$ with the $(S)$-configuration (entries 1-2). The reductions of $\mathbf{1 0}$ and $\mathbf{1 3}$. followed by deprotection, oxidation. $\mathrm{S}_{\mathrm{S} 2}$ type azidation and catalytic hydrogenation according to the salne procedure described in route $\mathrm{I}-3$ using method $\mathrm{A}$ afforded $(I R, 2 R)-2$ with $89 \%$ ee from $9 \mathrm{a},(\mid R, 2 R)-2$ with $93 \%$ ee and $(R)-3$ with $93 \%$ ee from $9 b,(1 R, 2 S)-1$ with $96 \%$ ee and $(S)-3$ with $96 \%$ ee from 11 and $(1 R, 2 S)-1$ with $78 \%$ ee from 14 . In this reduction, unreacted ketones which are $(S)-10$ with $46 \%$ ee and $(S)-13$ with $95 \%$ ee were recovered in $33 \%$ and $38 \%$ yields, respectively (entries 3 and 4 ). With the same manner described in method A. $(R)-3$ with $93 \%$ ee and (S)-3 with $96 \%$ ee were obtained in 82 and $89 \%$ yields by oxidation of $9 \mathrm{~b}$ and $8 \mathrm{a}$. followed by deprotection. All the reductions using method B produced the syn products preferentially, such as the antissun ratios $45: 55$ for $7 \mathbf{a}, 38: 62$ for $7 \mathbf{b}, 17.3: 82.7$ for 10 and 0 : 100 for 13. Especially, it is noteworthy in a practical aspect that the reduction of $\mathbf{1 3}$ afforded only the syn products. In general, it has been known that reductions with 6 proceed through a cyclic, six-membered transition-state reminiscent of the Meerwein-P'ondorf-Verley (MPV) processes and their enantioselectivities are induced by stereodifferential control of the methyl group at the 2-position of a-pinene to prochiral ketones (Figure 2). ${ }^{21}$ Based on this proposed mechanism, preferential formation of the $s y n$ products can be explained by the Cram open-chain model shown in Scheme 3 where hydride more favorably approaches the carbon of the

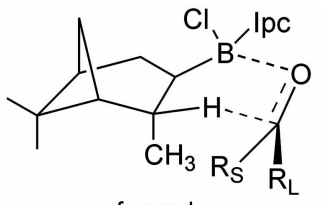

favored

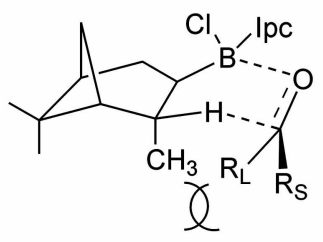

less favored
$(2 R)-7,10$ and 13

favorable

$9 a, b, 12$ and 14

syn products

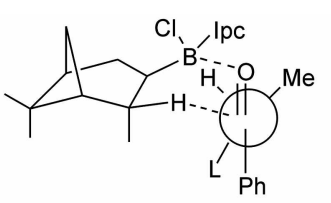

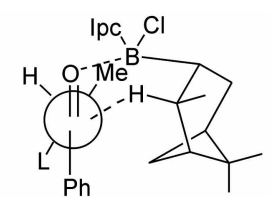

(2R)-7,10 and 13

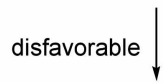

ent-8a, b, ent-11 and ent-15

anti products

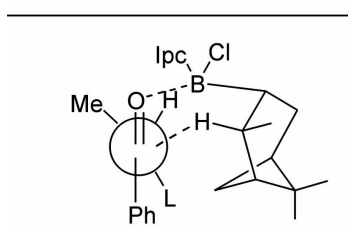

(2S)-7,10 and 13

favorable

ent-9a,b, ent-12 and ent-14

syn products

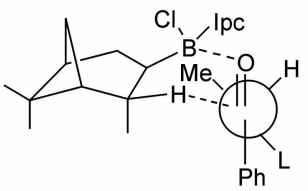

(2S)-7,10 and 13
$8 a, b, 11$ and 15

anti products

Scheme 3

carbonyl group from the least hindered side in both $(2 R)$ and (2S)-prochiral ketones. Unlike CBS reduction, formation of the $s y n$ products as the major product from 7 might be attributable to a strong coordination of Lewis acid-typed reducing agent 6 on oxygen of the carbonyl. The enantiomeric purities of the unreacted ketones recovered are in good correspondences with those calculated from diastereomeric ratios of the corresponding product alcohols. This indicates that all the reductions by method $\mathrm{B}$ are also included with double asymmetric induction via partial kinetic resolutions.

\section{Conclusion}

We have developed a new synthetic route for preparation of optically active norephedrine 1. norpseudoephedrine $\mathbf{2}$ and cathinone 3 by employing asymmetric reduction of $\mathrm{N}$ protected 2-amino-1-phenylpropanone 7, 2-azido-1-phenylpropanone $\mathbf{1 0}$ and 2-methanesulfonyloxy-1-phenylpropanone 13 using $\mathrm{CBS}$-reagent (method $\mathrm{A}$ ) and ${ }^{\prime} \mathrm{Jpc}_{2} \mathrm{BCl}$ ( $($ nethod B) as chiral reducing agents under kinetic and nonkinetic conditions and found out that the reductions were included with double asymonetric induction via partial kinetic resolution. To our best knowledge, this is the first example for kinetic resolution of acyclic racemic ketones using these chiral reducing agents. The best results from method A were achieved by reduction of 10 and 13 to give $(1 S, 2 R)-1$ with $76 \%$ ee and $(1 S, 2 S)-2$ with $78 \%$ ee. Method B notably provided $(1 R, 2 S)-\mathbf{1}$ and $(S)-3$ with $96 \%$ ee from 11 and $(1 R, 2 R)-2$ and $(R)-3$ with $93 \%$ ee from $9 \mathrm{~b}$. Especially, only single isomer $(I R, 2 S)$-1 with $78 \%$ ee was obtained from reduction of $\mathbf{1 3}$ using method $\mathrm{B}$. This methodology provides alternative routes for preparation of chiral 1-3, which are of 
great importance as biologically active substances and chiral auxiliaries, ligands and catalysts for a variety of asymmetric synthesis.

\section{Experimental Section}

General. All operations with air-sensitive materials were carried out under a nitrogen atmosphere with oven-dried glassware. Liquid materials were transferred with a donbleended needle. The reactions were monitored by TLC using silica gel plates and the products were purified by a flash column chromatography on silica gel (Merck: 230-400 mesh). NMR spectra were recorded at 200.300 or $400 \mathrm{MHz}$ for ${ }^{1} \mathrm{H}$ and 50,75 or $100 \mathrm{MHz}$ for ${ }^{13} \mathrm{C}$ using $\mathrm{Me} \mathrm{C}_{4} \mathrm{Si}$ as the internal standard in $\mathrm{CDCl}_{3}, \mathrm{CD}_{3} \mathrm{OD}$ or $\mathrm{D}_{2} \mathrm{O}-\mathrm{DCl} . J$-values are given in $\mathrm{Hz}$. Optical rotations were measured with a high resolution digital polarimeter. $[\alpha]_{D}$-values are given in units of $10^{-1} \mathrm{deg} \mathrm{cm}^{2} \mathrm{~g}^{-1}$. Melting points were uncorrected. Enantiomeric excesses (e.e.s) of the products were determined with a HPLC apparatus fitted with a $25 \mathrm{~cm}$ Whelk-Ol (Regis) chiral column.

Materials. Most of organic compounds utilized in this study were conumercial products of the highest purity. They were further purified by distillation when necessary. THF was distilled over sodium benzophenone ketyl and stored in ampules under nitrogen atmosphere. The (S)-MeCBS reagent $4 . N$-etly $l-N$-isopropy laniline-borane complex 5 and $(-)$ - $B$-chlorodiisopinocampheylborane (" $\mathrm{Ipc}=\mathrm{BCl}$. 6) were purchased from the Aldrich Chenical Company

General procedure for asymmetric reduction of 7, 10 and 13 using (S)-MeCBS-oxazaborolidine-catalyzed borane $(\operatorname{method} A)$ and $(-)-B$-chlorodiisopinocampheyl-borane ( ${ }^{d} \mathrm{Ipc}_{2} \mathrm{BCl}$; method B). Method A: To a solution of $4(0.2$ mmol; $0.2 \mathrm{M} .1 .0 \mathrm{~cm}^{3}$ ) in THF was added a solution of $N$ ethyl- $N$-isopropy laniline-borane complex 5 [2.0 munol: 2.0 M. $1.0 \mathrm{~mL}$ for non-kinetic condition; or $0.34 \mathrm{~mm} / \mathrm{l}: 0.34 \mathrm{M}$. $1 \mathrm{~mL}$ for kinetic condition] in THF. To this was added slowly $2 \mathrm{~mL}$ of THF solution of ketones 7.10 or 13 . (2 mmol) over a period of $1.5 \mathrm{~h}$ using a syyringe pump at $25^{\circ} \mathrm{C}$. After the addition. the reaction mixture was stirred for 10 min. quenched cautiously with methanol $\left(0.5 \mathrm{~cm}^{3}\right)$. and stirred for additional $30 \mathrm{~min}$. The solvent was evaporated under reduced pressure. The crude product alcohols obtained were further purified by a flash column chromatography on silica gel (230-400 mesh) using appropriate solvents as eluent.

Method B: An oven-dried. $10 \mathrm{~mL}$ round bottom flask equipped with a septum-capped side arm. magnetic stirring bar. and a connecting tube was cooled to room temperature in a stream of nitrogen. "Ipc $\mathrm{C}_{2} \mathrm{BCl}(6,786 \mathrm{mg} .2 .4 \mathrm{mmol})$ was transferred to the flask in a glove bag and dissolved in THF $\left(0.5 \mathrm{~mL}\right.$ ). The solution was cooled to $0^{\circ} \mathrm{C}$ and $2 \mathrm{~mL}$ of THF solution of 7.10 . or $13(2.0 \mathrm{~mm}$ ol $)$ was added. The reaction mixture was maintained at $0{ }^{\circ} \mathrm{C}$. After $72 \mathrm{~h}$, to this was added acetaldehy'de (160 mg. $3.6 \mathrm{mmol}$ ) dropwise at the same temperature. The mixture was warmed to room temperature and stirred for $4 \mathrm{~h}$. After solvent was evaporated under reduced pressure. the residue was purified by a flash column cluromatography on silica gel (230-400 mesh) using appropriate solvents as eluent. All the reductions examined in this study proceeded incompletely under these reaction conditions to be recovered $33-52 \%$ of starting materials from the reaction mixtures.

To determine absolute configuration of product alcohols. authentic 8a, 8b, 9a and 9b were prepared by treating $(I R, 2 S)$-norephedrine 1 and $(I R .2 R)$-norpseudoephedrine 2 with $\mathrm{Boc}_{2} \mathrm{O}$ and $\mathrm{Cbz}-\mathrm{Cl}$ according to the literature ${ }^{19} 8 \mathrm{a}$ : $\mathrm{mp}$ $91-92^{\circ} \mathrm{C}\left(\right.$ lit $\left.^{{ }^{y / 4}} 91-93{ }^{\circ} \mathrm{C}\right) ;[\alpha]_{\mathrm{D}}^{30}=-68.97\left(c 1.02, \mathrm{CHCl}_{3}\right)$, $>99 \%$ ee $\left\{\right.$ lit. ${ }^{\gamma_{4}}[\alpha]^{25}=-63\left(c 0.06, \mathrm{CHCl}_{3}\right) .95 \%$ ee $\} .8 \mathbf{b}$ : mp $94-95{ }^{\circ} \mathrm{C} ;[\alpha]_{\mathrm{D}}^{30}=-44.6\left(c 1.06, \mathrm{CHCl}_{3}\right) .>99 \%$ ee. $9 \mathrm{a}$ $\operatorname{mp} 84-85^{\circ} \mathrm{C}$ (lit. $\left.{ }^{9 \mathrm{a}} 85.87^{\circ} \mathrm{C}\right) ;[\alpha]_{\mathrm{D}}^{20}=37.58\left(c 1.02, \mathrm{CHCl}_{3}\right)$, $>99 \%$ ee $\left\{\right.$ lit $\left.^{{ }^{2}}[\alpha]_{\mathrm{J}}{ }^{25}=-32\left(c 0.05, \mathrm{CHCl}_{3}\right) .1 R, 2 R\right\} .9 \mathrm{~b}: \mathrm{mp}$ $62-63{ }^{\circ} \mathrm{C} ;[\alpha]_{\mathrm{D}}^{20}=-40.51\left(c 1.21 . \mathrm{CHCl}_{3}\right) .>99 \%$ ee.

\section{A) Reduction of 7 by method $A$.}

A1) Reduction of $7 \mathrm{a}$ (non-kinetic conditions: use of 1.0 equiv. of 5): $96 \%$ yield (as diastereomeric mixture); white solid: HPLC analysis using a $25 \mathrm{~cm}$ Whelk-OI chiral column showed a composition of $44 \% 8 \mathrm{a}, 16 \%$ ent-8a, $34 \%$ 9a and $6 \%$ ent-9a [analytical conditions: $i s o-\mathrm{PrOH} /$ hexane: 1/99: flow rate: $0.7 \mathrm{~mL} / \mathrm{min}$; detector: $254 \mathrm{~nm}: t_{\mathrm{R}} 25.99 \mathrm{~min}$ for $8 \mathrm{a}, t_{\mathrm{K}} 29.60 \mathrm{~min}$ for $e n t-8 \mathrm{a}$. $t_{\mathrm{R}} 32.63 \mathrm{~min}$ for $9 \mathrm{a}$ and $t_{\mathrm{k}}$ $38.12 \mathrm{~min}$ for $e n t-9 \mathrm{a}]$. which exhibited the formation of $\mathbf{8 a}$ with $48 \%$ ee and $9 \mathrm{a}$ with $70 \%$ ee.

A2) Reduction of 7 a (kinetic conditions: use of 0.17 equiv. of 5): $40 \%$ yield (as diastereomeric mixture); white solid; HPLC analysis under the same analytical conditions as described above shoved a composition of $64 \% 8 \mathrm{a} .10 \%$ ent-8a, 20\% 9a and 6\% ent-9a. Unreacted ketone $7 \mathrm{a}$ was recovered in $53 \%$ yield. $R_{\mathrm{f}} 0.25$ : white solid; $\mathrm{mp} 68-70{ }^{\circ} \mathrm{C}$ (lit. ${ }^{\text {ys }} 70-722^{\circ} \mathrm{C}$ ), IR $\left(\mathrm{KBr}, \mathrm{cm}^{-1}\right) 3336.2973 .1710 .1682:{ }^{1} \mathrm{H}$ $\operatorname{NMR}\left(200 \mathrm{MHz} . \mathrm{CDCl}_{3}\right) \delta 1.40\left(3 \mathrm{H}, \mathrm{d}, J=7.3, \mathrm{CH}_{3}\right), 1.46$ (9H. s. $\left.\mathrm{C}\left(\mathrm{CH}_{3}\right)_{3}\right), 5.30(\mathrm{lH}$, quintet. $J=7.0, \mathrm{CHNH}) .5 .55$ (lH. br s. NH). $7.49-7.61(3 \mathrm{H}, \mathrm{m}), 7.98(2 \mathrm{H}$. d. $J=8.2)$ $(\mathrm{Ar} H) ;{ }^{13} \mathrm{C}$ NMR $\left(50 \mathrm{MHz}, \mathrm{CDCl}_{3}\right) \delta 20.5 \mathrm{l}\left(\mathrm{CH}_{3}\right), 29.02$ $\left(\mathrm{C}\left(\mathrm{CH}_{3}\right)_{3}\right), 51.85(\mathrm{CHNH}) .80 .40\left(\mathrm{CMe}_{3}\right), 129.43 .134 .45$, 135.02. 135.10 (Ar-C). 155.93 (NHCO). 200.20 (PhCO): Its enantiomeric purty determined by HPLC analysis using the same column [iso-PrOH/hexane: 1/9: flow rate: $0.5 \mathrm{~mL} / \mathrm{min}$ : detector: $254 \mathrm{~nm}: t_{\mathrm{R}}(2 S) 9.84 \mathrm{~min}$ and $t_{\mathrm{R}}(2 R) 13.23 \mathrm{~min}$ ] showed it to be $27 \%$ ee with the $(R)$-configuration.

A3) Reduction of $7 \mathrm{~b}$ (non-kinetic conditions: use of 1.0 equiv. of 5): $95 \%$ yield (as diastereomeric mixture): white solid: HPLC analysis using a $25 \mathrm{~cm}$ Whelk-O1 chiral column showed a composition of $41 \% 8 \mathrm{~b} .24 \%$ ent-8b. $27 \%$ $9 \mathrm{~b}$ and $8 \%$ ent-9b [analytical conditions: $i s o-\mathrm{PrOH} /$ hexane: 1/40: flow rate: $0.7 \mathrm{~mL} / \mathrm{min}$ : detector: $254 \mathrm{~nm}: t_{\mathrm{R}} 44.50 \mathrm{~min}$ for $8 \mathrm{~b}, t_{\mathrm{K}} 48.04 \mathrm{~min}$ for $e n t-8 \mathrm{~b}, t_{\mathrm{K}} 55.08 \mathrm{~min}$ for $e n t-9 \mathrm{~b}$ and $t_{\mathrm{R}} 57.62 \mathrm{~min}$ for $\mathbf{9 b}$ ]. which exhibited the formation of $\mathbf{8 b}$ with $26 \%$ ee and $9 b$ with $55 \%$ ee.

At) Reduction of $7 \mathrm{~b}$ (kinetic conditions: use of 0.17 equiv. of 5): $45 \%$ yield (as diastereomeric mixture): white solid: HPLC analysis under the same analytical conditions as described above showed a composition of $57 \% 8 \mathrm{~b} .15 \%$ ent-8a. $19 \% 9$ a and $9 \%$ ent-9a. Unreacted ketone $7 \mathbf{b}$ was recovered in $47 \%$ yield: $R_{\mathrm{f}} 0.54$ (eluent: EtOAc/hexane 1 : 
2): white solid; mp $88-89{ }^{\circ} \mathrm{C}$; IR $\left(\mathrm{KBr} . \mathrm{cm}^{-1}\right) 3378,1707$. 1696; ${ }^{1} \mathrm{H}$ NMR $\left(200 \mathrm{MHz}, \mathrm{CDCl}_{3}\right) \delta 1.44(3 \mathrm{H} . \mathrm{d} . J=7.0$. $\mathrm{CH}_{3}$ ). 5.14 (2H. s.PhCH:) 5.33 (lH. quintet, $J=7.2$. $\mathrm{C} H \mathrm{NH}), 5.89(1 \mathrm{H}$, br s, $\mathrm{CHN} H), 7.26-8.00(10 \mathrm{H}, \mathrm{m} . \mathrm{Ar} H)$ : ${ }^{13} \mathrm{C} \mathrm{NMR}\left(50 \mathrm{MHz}, \mathrm{CDCl}_{3}\right) \delta 20.62\left(\mathrm{CH}_{3}\right), 52.32(\mathrm{CHNH})$. $67.50\left(\mathrm{PhCH}_{2}\right) .128 .80,129.38 .134 .58,134.68 .137 .10$ (ArC). 156.33 (NHCO). 199.61 (PhCO). Its enantiomeric purty determined by HPLC analysis using the same column [iso$\mathrm{PrOH} /$ hexane: $1 / 4$ : flow rate: $1.1 \mathrm{~mL} / \mathrm{min}$ : detector: $254 \mathrm{~mm}$ : $t_{\mathrm{R}}(2 \mathrm{~S}) 6.62 \mathrm{~min}$ and $t_{\mathrm{R}}(2 R) 13.82 \mathrm{~min}$ ] showed it to be $26 \%$ ee with the $(R)$-configuration.

\section{B) Reduction of 10 .}

B1) Reduction of 10 (non-kinetic conditions: use of 1.0 equiv. of 5): The reduction of $\mathbf{1 0}$ provided an inseparable mixture of product alcohols 11, ent-11. 12 and ent-12 in $97 \%$ yield by a flash column chromatography on silica gel: oil: IR (neat. $\left.\mathrm{cm}^{-1}\right) 3424.2978 .2102 ;{ }^{1} \mathrm{H}$ NMR $(200 \mathrm{MHz}$. $\left.\mathrm{CDCl}_{3}\right) \delta 1.12\left(2 . \mathrm{lH} . \mathrm{d}, J=6.7, \mathrm{CH}_{3}^{\mathrm{i}}\right), 1.20(0.9 \mathrm{H}, \mathrm{d} . J=$ 6.4. $\left.\mathrm{CH}_{3}{ }_{3}\right), 2.20\left(0.3 \mathrm{H}, \mathrm{d} . J=3.4 . \mathrm{OH}^{-1}\right) .2 .49(0.7 \mathrm{H} . \mathrm{d}, J=$ 3.1. $\left.\mathrm{OH}^{\mathrm{B}}\right), 3.68\left(\mathrm{IH} . \mathrm{m}, \mathrm{C} H \mathrm{~N}_{3}\right), 4.47(0.7 \mathrm{H}$. dd. $J=3.1 .7 .3$. $\left.\mathrm{C} H^{-} \mathrm{OH}\right), 4.75\left(0.3 \mathrm{H}, \mathrm{t}, J=4.0, \mathrm{CH}^{B} \mathrm{OH}\right), 7.26-7.36(5 \mathrm{H} . \mathrm{m}$. $\mathrm{Ar} H) ;{ }^{13} \mathrm{C}$ NMR $\left(50 \mathrm{MHz} . \mathrm{CDCl}_{3}\right) \delta 13.90\left(\mathrm{C}^{i} \mathrm{H}_{3}\right), 16.34$ $\left(C^{B} \mathrm{H}_{3}\right) .62 .77\left(C^{\mathrm{i}} \mathrm{HN}_{3}\right), 63.95\left(C^{B} \mathrm{HN}_{3}\right) .76 .81\left(C^{i} \mathrm{HOH}\right)$. $78.54\left(C^{8} \mathrm{HOH}\right), 126.85,127.18,128.52 .128 .86 .129 .02$, $1+0.51$ (Ar-C); A mixture of the azido alcohol (2 mmol). $\mathrm{Boc}_{2} \mathrm{O}(2.4 \mathrm{mmol})$ and $10 \% \mathrm{Pd} / \mathrm{C}(40 \mathrm{mg})$ in EtOAc $\left(2 \mathrm{~cm}^{3}\right)$ was hydrogenated using hydrogen balloon at room temperature for $24 \mathrm{~h}$. filtered on a celite pad and the filtrate was concentrated to give a mixture of $8 \mathbf{a}$ or ent-8a and $9 \mathbf{a}$ or ent9 a in $89 \%$ yield. HPLC analysis of the product $N$-Boc anino alcohols displayed a composition of $5 \%$ 8a. $24 \%$ ent-8a. $26 \% 9 \mathrm{a}$ and $45 \%$ ent $-9 \mathrm{a}$.

B2) Reduction of 10 (kinetic conditions: use of 0.17 equiv. of 5): $43 \%$ yield (as diastereomeric mixture): oil: After the mixture of product alcohols were converted into $\mathrm{N}$ Boc amino alcohols according to the procedure previously mentioned. HPLC analysis showed a composition of $10 \%$ 8a. $22 \%$ ent-8a. 19\% 9a and 49\% ent-9a. Unreacted ketone 10 was recovered in $50 \%$ yield: $R_{\mathrm{f}} 0.63$ (eluent: $\mathrm{EtOAC}$ hexane 1:2): oil: IR (neat. $\mathrm{cm}^{-1}$ ) 2986. 2123. 1698: ${ }^{1} \mathrm{H}$ NMR $\left(300 \mathrm{MHz}, \mathrm{CDCl}_{3}\right) \delta 1.56\left(3 \mathrm{H}\right.$, d. $\left.J=6.9, \mathrm{CH}_{3}\right) .4 .70$ $(1 \mathrm{H} . \mathrm{q} . J=7.0 . \mathrm{CHN}$ ). $7.47-7.59(3 \mathrm{H} . \mathrm{m}) .7 .90-7.93(2 \mathrm{H} . \mathrm{m}$. $\mathrm{ArH}):{ }^{13} \mathrm{C}$ NMR $\left(75 \mathrm{MHz} . \mathrm{CDCl}_{3}\right) 16.89\left(\mathrm{CH}_{3}\right) .58 .87$ $\left(\mathrm{CHN}_{\mathrm{s}}\right) .128 .83,129.12,134.12,134.40$ (Aг-C) 196.80 (PhCO): Anal calcd for $\mathrm{C}_{3} \mathrm{H}_{3} \mathrm{O}: \mathrm{C}, 61.70: \mathrm{H}, 5.18 ; \mathrm{N}$. 23.99. Found: C. $61.53:$ H. $5.14:$ N . 24.04\%. After 10 was converted into $7 \mathrm{a}$ its enantiomeric purity determined by HPLC analy'sis with the same analytical condition described above was found to be $18 \%$ ee with the $(R)$-configuration.

\section{C) Reduction of 13.}

C1) Reduction of 13 (non-kinetic conditions: use of 1.0 equiv of 5): The reduction of $\mathbf{1 3}$ provided a mixture of 1,2diol monomesy lates 14. ent-14. 15 and ent-15 in $98 \%$ yield. which were not separated by a flash column chromatography' on silica gel: white solid: $\mathrm{IR}\left(\mathrm{KBr}, \mathrm{cm}^{-1}\right) 3499.1344,1173$ : $\delta_{\mathrm{H}} \mathrm{NMR}\left(400 \mathrm{MHz}, \mathrm{CDCl}_{3}\right) 1.25(2.16 \mathrm{H} . \mathrm{d} . J=6.46$. $\left.\mathrm{CH}^{\mathrm{A}}{ }_{3}\right) .1 .34\left(0.84 \mathrm{H}\right.$. d. $\left.J=6.30, \mathrm{CH}^{B}{ }_{3}\right) .2 .58(0.28 \mathrm{H}$, br s.
$\left.\mathrm{OH}^{1}\right) .2 .73\left(0.72 \mathrm{H} . \mathrm{d}, J=3.52, \mathrm{O} H^{B}\right), 2.81(0.84 \mathrm{H} . \mathrm{s}$, $\left.\mathrm{CH}_{3}^{4} \mathrm{SO}_{2}\right) .2 .94\left(2.16 \mathrm{H}\right.$. s. $\left.\mathrm{CH}_{3}^{{ }_{3}} \mathrm{SO}_{2}\right), 4.66(0.72 \mathrm{H}, \mathrm{dd} . J=$ $\left.3.30,7.10, \mathrm{C} H^{\circ} \mathrm{OH}\right), 4.84(\mathrm{lH}$, quintet. $J=6.65 . \mathrm{CHOMs}$ ), $4.89\left(0.28 \mathrm{H}\right.$. d. $\left.J=4.29, \mathrm{C} H^{E} \mathrm{OH}\right), 7.26-7.38(5 \mathrm{H}$. m. $\mathrm{Ar} H)$; ${ }^{13} \mathrm{C}$ NMR $\left(100 \mathrm{MHz} . \mathrm{CDCl}_{3}\right) \delta 15.84\left(\mathrm{C}^{\mathrm{H}} \mathrm{H}_{3}\right) .18 .16\left(\mathrm{C}^{6} \mathrm{H}_{3}\right)$, $38.20\left(C^{3} \mathrm{H}_{3} \mathrm{SO}_{2}\right) .38 .29\left(C^{6} \mathrm{H}_{3} \mathrm{SO}_{2}\right) .77 .57$ (CHOMs). 82.50 $\left(C^{2} \mathrm{HOH}\right) .83 .50\left(\mathrm{C}^{6} \mathrm{HOH}\right) .126 .75 .126 .90,128.37,128.53$. $128.74,128.78,139.09 .139 .32\left(\mathrm{Ar}-C^{d, B}\right)$ : Anal cald for $\mathrm{C}_{10} \mathrm{H}_{14} \mathrm{O}_{4} \mathrm{~S}: \mathrm{C} .52 .16: \mathrm{H}, 6.13$ : S. 13.92. Found: C. 52.33; H. 6.24: S. $14.04 \%$ : A mixture of 1.2-diol monomesylates (1 mmol) and sodium azide (1.2 mmol) in DMSO (2 mL) was heated at $80^{\circ} \mathrm{C}$ for $2 \mathrm{~h}$ and then cooled to room temperature. To this was added water $(2 \mathrm{~mL})$ and the mixture was extracted with $\mathrm{CH}_{2} \mathrm{Cl}_{2}(3 \times 5 \mathrm{~mL})$. The combined extract was dried over anhydrous $\mathrm{MgSO}_{4}$, filtered and concentrated. The crude product obtained was further purified by a flash column chromatograply on silica gel (230-400 mesh) using ethyl acetate/hexane $(\mathrm{L} / 2)$ as eluent to give a mixture of 2azido-l-phenylpropanols in $82 \%$ yield. According to the procedure described above, the azido alcohols obtained were converted into $N$-Boc amino alcohols, 8a ent-8a, 9a and ent9a. HPLC analysis of these showed a composition of $25 \%$ 8a, $46 \%$ ent-8a. $3 \% 9$ a and $26 \%$ ent -9 a.

C2) Reduction of 13 (kinetic conditions: use of 0.17 equiv of 5): $40 \%$ yield (as diastereomeric mixture); white solid: After the mixture of product alcohols were converted into $N$-Boc amino alcohols. its HPLC analysis showed a composition of $20 \% 8 \mathrm{a}, 52 \%$ ent $-8 \mathrm{a}, 6 \% 9 \mathrm{a}$ and $22 \%$ ent-9a. Unreacted ketone 13 was recovered in $54 \%$ yield. $R_{i} 0.31$ (eluent: EtOAc/hexane 1:2); white solid: mp $92-94{ }^{\circ} \mathrm{C}$ : IR $\left(\mathrm{KBr}, \mathrm{cm}^{-1}\right)$ 3016. 1696. 1357. 1175; ${ }^{1} \mathrm{H}$ NMR $(300 \mathrm{MHz}$, $\left.\mathrm{CDCl}_{3}\right) \delta 1.66\left(3 \mathrm{H}, \mathrm{d}, J=7.2, \mathrm{CH}_{3}\right) .3 .14\left(3 \mathrm{H}\right.$. s. $\left.\mathrm{CH}_{3} \mathrm{SO}_{2}\right)$, 6.04 (l H. q. $J=7.0, \mathrm{CHOMs}$ ), 7.47-7.65 (3H. m). 7.90-7.94 (2H. m. ArH): ${ }^{12} \mathrm{C}$ NMR (75 MHz. CDCl $) \delta 19.14\left(\mathrm{CH}_{3}\right)$, $39.79\left(\mathrm{CH}_{3} \mathrm{SO}_{2}\right), 77.45$ (CHOMs). 128.81, 129.21. 133.82, 134.39 (Ar-C), 195.37 (PhCO); Anal. calcd. for $\mathrm{C}_{10} \mathrm{H}_{12} \mathrm{O}_{4} \mathrm{~S}$ : C, 52.62: H. 5.30: S, 14.05. Found: C. $52.33 ; \mathrm{H}, 5.41 ; \mathrm{S}$. $14.04 \%$ : Its enantiomeric purty determined by HPLC analysis [analytical conditions: iso- $\mathrm{PrOH} / \mathrm{h}$ exane: $1 / 9$ : flow rate: $1.0 \mathrm{~mL} / \mathrm{min}$ : detector: $254 \mathrm{~nm}: t_{\mathrm{R}}(2 S) 13.13 \mathrm{~min}$ and $t_{\mathrm{R}}$ (2R) $24.48 \mathrm{~min}$ ] showed it to be $9 \%$ ee with $(R)$ configuration.

D) Reduction of 7 by method $B$.

D1) Reduction of $7 \mathrm{a}: 48 \%$ yield (as diastereomeric mixture): white solid: HPLC analy sis showed a composition of $31 \% \mathbf{8 a} .14 \%$ ent-8a. $52 \%$ a and $3 \%$ ent-9a, which exhibited the formation of $8 \mathrm{a}$ with $38 \%$ ee and $9 \mathrm{a}$ with $89 \%$ ee. (S)-7a with $31 \%$ ee was recovered in $46 \%$ yield.

D2) Reduction of $7 \mathrm{~b}: 40 \%$ yield (as diastereomeric mixture): white solid: HPLC analy sis showed a composition of $30 \% \mathbf{8 b} .8 \%$ ent $-\mathbf{8 b}, 60 \% \mathbf{9 b}$ and $2 \%$ ent $-9 \mathbf{b}$, which exhibited the fonmation of $8 \mathrm{~b}$ with $58 \%$ ee and $9 \mathrm{~b}$ with $93 \%$ ee. (S)-7b with $19 \%$ ee was recovered in $52 \%$ yield.

E) Reduction of $10.60 \%$ yield (as diastereomeric mixture): oil: After product alcohols were converted into $N$ Boc amino alcohols. HPLC analysis showed a composition of $17 \% 8 \mathbf{a}$. $0.3 \%$ ent-8a. $64.7 \% 9$ a and $18 \%$ ent -9 a which 
exhibited the formation of $8 \mathrm{a}$ with $96 \%$ ee and $9 \mathrm{a}$ with $56 \%$ ee. (S)-10 with $46 \%$ ee was recovered in $33 \%$ yield. $R_{0} 0.63$ (eluent: EtOAc/hexane $1: 2$ ); oil; $[\alpha]_{\mathrm{D}}^{20}=+65.92$ (c 1.09 . $\mathrm{CHCl}_{3}$ ).

F) Reduction of $13.55 \%$ yield as only $14: R_{\mathrm{f}} 0.25$ (eluent: EtOAc/hexane $1: 2$ ); white solid: mp $81-82^{\circ} \mathrm{C}$; IR (KBr. $\mathrm{cm}^{-1}$ ) 3524, 1337. 1172; ${ }^{1} \mathrm{H}$ NMR (400 MHz. $\left.\mathrm{CDCl}_{3}\right) \delta 1.25$ $\left(3 \mathrm{H}, \mathrm{d}, J=6.46 . \mathrm{CH}_{3}\right), 2.73(1 \mathrm{H}, \mathrm{d}, J=3.52 . \mathrm{OH}) .2 .94$ (3 $\mathrm{H}$, s. $\left.\mathrm{CH}_{3} \mathrm{SO}_{2}\right), 4.66(\mathrm{l} \mathrm{H}, \mathrm{dd}, J=3.30 .7 .10 . \mathrm{CHOH}), 4.84$ (l H. quintet. $J=6.65 . \mathrm{CHOMs}) .7 .26-7.38(5 \mathrm{H}, \mathrm{m} . \mathrm{Ar} H$ ): ${ }^{13} \mathrm{C} \mathrm{NMR}\left(100 \mathrm{MHz}, \mathrm{CDCl}_{3}\right) \delta 18.16\left(\mathrm{CH}_{3}\right) .38 .29\left(\mathrm{CH}_{3} \mathrm{SO}_{2}\right)$. 77.57 (CHOMs), $83.50(\mathrm{CHOH}), 126,90,128.53 .128 .74$. $139.32(\mathrm{Ar}-\mathrm{C}) ;[\alpha]_{\mathrm{D}}^{18}=.39 .29\left(\mathrm{c} 1.06, \mathrm{CHCl}_{3}\right) ; \mathrm{HPLC}$ analysis of $8 \mathrm{a}$ prepared from 14 showed it to be $78 \%$ ee. (S)-13 with $95 \%$ ee was recovered in $38 \%$ yield: $[\alpha]_{D}^{18}=-106.92(c$ $0.99, \mathrm{CHCl}_{3}$ )

Isolation of optically active 8 and 9.

A) $(1 R, 2 S)-N$-Boc-norephedrine $8 \mathrm{a}$. Reductions of $7 \mathrm{a}$ using method $A$ and 10 using method $B$ are representative (Table 1. entry 2 and Table 2 . entry 3). 57\% yield from $7 \mathbf{a}$ and $9 \%$ yield from 10 by catalytic hydrogenation according to aforementioned procedure; $R_{\mathrm{f}} 0.39$ (eluent: EtOAc/hexane $1: 2$ ); white solid: $\mathrm{mp} 85-86^{\circ} \mathrm{C}$ (lit $\left.{ }^{15} 91-93^{\circ} \mathrm{C}\right)$. IR $\left(\mathrm{KBr} \cdot \mathrm{cm}^{-1}\right)$ 3403. 3375, 2980. 1684; ${ }^{1} \mathrm{H}$ NMR (200 MHz. $\left.\mathrm{CDCl}_{3}\right) \delta 0.98$ $\left(3 \mathrm{H}, \mathrm{d}, J=6.7, \mathrm{CH}_{3}\right), 1.46\left(9 \mathrm{H}, \mathrm{s}, \mathrm{C}\left(\mathrm{CH}_{3}\right)_{3}\right) .3 .31(1 \mathrm{H} . \mathrm{br} \mathrm{s}$. $\mathrm{NH}), 4.0(1 \mathrm{H}, \mathrm{m} . \mathrm{CHNH}) .4 .67(\mathrm{l} \mathrm{H} . \mathrm{br}, \mathrm{OH}), 4.85(\mathrm{l} \mathrm{H}$. $\mathrm{m}, \mathrm{CHOH}) .7 .26-7.36(5 \mathrm{H} . \mathrm{m}, \mathrm{ArH}):{ }^{1 .} \mathrm{C}$ NMR $(50 \mathrm{MHz}$. $\left.\mathrm{CDCl}_{3}\right) \delta 15.43\left(\mathrm{CH}_{3}\right) .29 .00\left(\mathrm{C}\left(\mathrm{CH}_{3}\right)_{3}\right) .52 .78(\mathrm{CHNH})$. $77.40\left(\mathrm{CMe}_{3}\right), 80.47(\mathrm{CHOH}) .127 .14 .128 .19 .128 .96 .141 .61$ (Ar-C). $157.08(\mathrm{NHCO})$ : Their optical purities determined by HPLC analysis were found to be $48 \%$ ee from $7 \mathrm{a}$ by method $\mathrm{A}$ and $96 \%$ ee from 10 by method $\mathrm{B}$ with the $(1 R .2 S)$-configuration $\left[t_{R}(1 R, 2 S) 25.99 \mathrm{~min}\right.$ and $t_{\mathrm{R}}(1 \mathrm{~S} .2 R)$ $29.60 \mathrm{~min}]:[\alpha]_{\mathrm{D}}^{30}=-30.5\left(c \quad 1.12 . \mathrm{CHCl}_{3}\right) .48 \%$ ee and $[\alpha]_{\mathrm{D}}^{20}=-67.28\left(c 1.09 . \mathrm{CHCl}_{3}\right) .96 \%$ ee $\left\{\right.$ lit. ${ }^{9 \mathrm{a}}[\alpha]_{\mathrm{J}}^{s 5}=-63(c$ $\left.0.06, \mathrm{CHCl}_{3}\right) .95 \%$ ee?

$(1 R, 2 S)-N$-Cbz-norephedrine 8b. Reduction of $7 \mathrm{~b}$ using method B is representative (Table 2 . entry 2 ). $15 \%$ yield: $R_{\mathrm{f}}$ 0.28 (eluent: EtOAc/hexane $1: 2$ ): white solid: $\mathrm{mp} 92-93^{\circ} \mathrm{C}$ : IR $\left(\mathrm{KBr} . \mathrm{cm}^{-1}\right)$ 3438. 3326. I686. I660; ${ }^{1} \mathrm{H}$ NMR (200 $\left.\mathrm{MHz} . \mathrm{CDCl}_{3}\right) \delta 0.99\left(3 \mathrm{H}\right.$. d. $\left.J=6.7 . \mathrm{CH}_{3}\right), 2.89(\mathrm{l} \mathrm{H}$. br s. $\mathrm{NH}) .4 .04(1 \mathrm{H} . \mathrm{m} . \mathrm{CHNH}) .4 .87(1 \mathrm{H}$. br s. $\mathrm{OH}) .5 .00(1 \mathrm{H}$. d. $J=7.9 . \mathrm{CHOH}) .5 .11\left(2 \mathrm{H} . \mathrm{s} . \mathrm{PhCH}_{2}\right) .7 .25 \cdot 7.35(10 \mathrm{H}$. m. $\mathrm{Ar} H):{ }^{13} \mathrm{C}$ NMR $\left(50 \mathrm{MHz} . \mathrm{CDCl}_{3}\right) \delta 15.09\left(\mathrm{CH}_{3}\right), 53.09$ $(\mathrm{CHNH}), 61.48\left(\mathrm{PhCH}_{2}\right), 67.55(\mathrm{CHOH}), 126.90 .128 .32$. 128.93. 137.13. 141.41 (Ar-C). 157.18 (NHCO): HPLC analysis showed it to be $58 \%$ ee with the $(1 R .2 S)$-configuration $\left[t_{\mathrm{R}}\right.$ (IR.2S) $44.50 \mathrm{~min}$ and $\left.t_{\mathrm{R}}(1 S .2 R)+8.04 \mathrm{~min}\right]$.

B) $(1 R, 2 R)-N$-Boc-norpseudoephedrine 9a. Reduction of $7 \mathbf{a}$ using method $B$ is representative (Table 2 . entry 1 ). $26 \%$ yield: $R_{\mathrm{f}} 0.32$ (eluent: EtOAc/hexane $1: 2$ ); white solid: mp 83-85 ${ }^{\circ} \mathrm{C}$ (lit. ${ }^{90} 85-87^{\circ} \mathrm{C}$ ); IR $\left(\mathrm{KBr}, \mathrm{cm}^{-1}\right.$ ) 3409. 3367. 2971. 1671: ${ }^{1} \mathrm{H}$ NMR $\left(200 \mathrm{MHz}, \mathrm{CDCl}_{3}\right) \delta 1.07(3 \mathrm{H}, \mathrm{d}, J=$ 6.7. $\left.\mathrm{CH}_{3}\right), 1.41\left(9 \mathrm{H}\right.$, s. C $\left.\left(\mathrm{CH}_{3}\right)_{3}\right) .3 .31(1 \mathrm{H}$. br s, $\mathrm{NH}), 3.88$ $(1 \mathrm{H}, \mathrm{m} . \mathrm{CHNH}) .4 .55(1 \mathrm{H} . \mathrm{dd} J=3.82 .5 .96 . \mathrm{CHOH}) .4 .66$ ( $1 \mathrm{H}$. br s. $\mathrm{OH}) .7 .27-7.35(5 \mathrm{H} . \mathrm{m} . \mathrm{ArH}):{ }^{13} \mathrm{C}$ NMR (50) $\left.\mathrm{MHz}, \mathrm{CDCl}_{i}\right) \delta 18.28\left(\mathrm{CH}_{3}\right), 29.00\left(\mathrm{C}\left(\mathrm{CH}_{i}\right)_{i}\right), 53.18$
$(\mathrm{CHNH}), 78.81\left(\mathrm{CMe}_{3}\right) .80 .47(\mathrm{CHOH}), 127.14 .128 .19$. 128.96, 142.41 (Ar-O) 157.19 (NHCO); HPLC showed it to be $89 \%$ ee with the $(I R, 2 R)$-configuration $\left[t_{\mathrm{K}}(I R, 2 R) 32.63\right.$ $\min$ and $\left.t_{\mathrm{R}}(\mathrm{IS}, 2 \mathrm{~S}) 38.12 \mathrm{~min}\right]_{{ }_{5}}[\alpha]_{\mathrm{D}}^{30}=-33.42(c 0.99$, $\left(\mathrm{CHCl}_{3}\right)$ for $89 \%$ ee $\left\{\right.$ lit. ${ }^{9_{a}}[\alpha]_{J}^{5}=-32\left(c 0.05 .\left(\mathrm{CHCl}_{3}\right)\right.$, $1 R, 2 R\}$.

C) $(1 R, 2 R)-N$-Cbz-norpseudoephedrine 9b. Reduction of $7 \mathrm{~b}$ using method B is representative (Table 2, entry 2). $24 \%$ yield; $R_{\mathrm{f}} 0.24$ (eluent: EtOAc/hexane $1: 2$ ); white solid: mp 61-62 ${ }^{\circ} \mathrm{C}: \mathrm{IR}\left(\mathrm{KBr}, \mathrm{cm}^{-1}\right) 3421.3303,1690.1542:{ }^{1} \mathrm{H}$ $\operatorname{NMR}\left(200 \mathrm{MHz} . \mathrm{CDCl}_{3}\right) \delta 1.11\left(3 \mathrm{H}, \mathrm{d}, J=6.7, \mathrm{CH}_{3}\right), 2.89$ (l H. br s. NH), 3.95 (I H. m. CHNH), 4.59 (l H. d, $J=5.5$, $\mathrm{OH}), 5.00(\mathrm{l} \mathrm{H} . \mathrm{d}, J=7.9, \mathrm{CHOH}) .5 .05(2 \mathrm{H}, \mathrm{s}, \mathrm{PhCH})_{2}$, 7.25-7.35 $(10 \mathrm{H}, \mathrm{m} . \mathrm{Ar} H) ;{ }^{12} \mathrm{C}$ NMR $\left(50 \mathrm{MHz} . \mathrm{CDCl}_{3}\right) \delta$ $18.32\left(\mathrm{CH}_{3}\right) .36 .93(\mathrm{CHNH}), 53.43\left(\mathrm{PhC} \mathrm{CH}_{2}\right), 67.45(\mathrm{CHOH})$. 127.19. 128.79, 129.17. 137.16. 142.06 (Ar-C), 157.31 (NHCO): HPLC analysis showed it to be $93 \%$ ee with the $(\mathrm{I} R, 2 R)$-configuration $\left[t_{\mathrm{K}}(\mathrm{IS}, 2 \mathrm{~S}) 55.08 \mathrm{~min}\right.$ and $t_{\mathrm{K}}(1 R, 2 R)$ $57.62 \mathrm{~min}]:[\alpha]_{\mathrm{D}}^{30}=37.60\left(c 1.35 . \mathrm{CHCl}_{3}\right)$.

Preparation of $(1 R, 2 S)$-norephedrine $(1 R, 2 S)-1$ from $8 \mathrm{a}$.

To a solution of $8 \mathrm{a}$ with $96 \%$ ee ( $1 \mathrm{mmol}$ ) in EtOAc (4 $\mathrm{mL}$ ) was added $3 N \mathrm{HCl}$ solution $(2 \mathrm{~mL})$ and stirred at room temperature for $1 \mathrm{~h}$. The mixture was basified with $6 \mathrm{~N}$ $\mathrm{NaOH}$ solution and extracted with $\mathrm{CH}_{2} \mathrm{Cl}_{2}(3 \times 5 \mathrm{~mL})$. The combined extract was dried over anhydrous $\mathrm{Na}_{2} \mathrm{SO}_{4}$, filtered, concentrated and crystallized with ether-hexane to give $(I R, 2 S)-1$ in $90 \%$ yield: white solid: $\mathrm{mp} 49-51^{\circ} \mathrm{C}$ (lit. ${ }^{2} 51-$ $\left.52{ }^{\circ} \mathrm{C}\right)$ : IR $\left(\mathrm{KBr} . \mathrm{cm}^{-1}\right) 3338,3063.1605,1452 ;{ }^{1} \mathrm{H}$ NMR $\left(200 \mathrm{MHz}, \mathrm{CDCl}_{3}\right) \delta 0.75\left(3 \mathrm{H} . \mathrm{d}, 3 \mathrm{H} . J=6.7 . \mathrm{CH}_{3}\right) .2 .40(3$ $\mathrm{H}$, br s, $\left.\mathrm{NH}_{2}+\mathrm{OH}\right) .3 .13$ (l H, quintet, $J=5.7 . \mathrm{CHNH}_{2}$ ), $4.50(\mathrm{l} \mathrm{H}, \mathrm{d}, J=4.6, \mathrm{CHOH}) .7 .23-7.37(5 \mathrm{H} . \mathrm{m} . \mathrm{Ar} H):{ }^{12} \mathrm{C}$ NMR $\left(50 \mathrm{MHz} . \mathrm{CDCl}_{3}\right) \delta 18.62\left(\mathrm{CH}_{3}\right), 52.64\left(\mathrm{CHNH}_{2}\right)$, $77.06(\mathrm{CHOH}) .127 .23,128.11,128.85,142.16(\mathrm{Ar}-\mathrm{C})$; HPLC analy sis of $\mathbf{8 a}$ obtained from treatment of this product with Boc $\mathrm{C}_{2} \mathrm{O}$ showed it to be $96 \% \mathrm{ee} ;[\alpha]_{\mathrm{D}}^{30}=-14.71(\mathrm{c} 1.83$, EtOH) $\left\{\right.$ lit. ${ }^{\text {st }}[\alpha]_{\mathrm{D}}^{3 \omega}=-14.6(c 3.4$. EtOH). $1 R, 2 S\}$.

Preparation of $(1 R, 2 R)$-norpseudoephedrine $(1 R, 2 R)$-2 from $9 b$.

A mixture of $9 \mathrm{~b}$ with $93 \%$ ee $(0.5 \mathrm{mmol})$ in $6 \mathrm{~N} \mathrm{HCl}$ solution $(2 \mathrm{~mL}$ ) was heated to reflux for $1 \mathrm{~h}$. The mixture was basified with $6 \mathrm{~N} \mathrm{NaOH}$ solution and extracted with $\mathrm{CH}_{2} \mathrm{Cl}_{2}(3 \times 5 \mathrm{~mL})$. The combined extract was dried over anhydrous $\mathrm{Na}_{2} \mathrm{SO}_{4}$, filtered. concentrated and crystallized with ether-hexane to give $(1 R, 2 R)-2$ in $89 \%$ yield: white solid: mp 60-61 ${ }^{\circ} \mathrm{C}$ : IR $\left(\mathrm{KBr} . \mathrm{cm}^{-1}\right)$ 3354. 3032. 1584, 1448 . ${ }^{1} \mathrm{H}$ NMR (200 MHz, $\mathrm{D}_{2} \mathrm{O}-1=N$ DCl)) $\delta 0.7 \mathrm{l}(3 \mathrm{H}, J=7.0$, $\left.\mathrm{CH}_{3}\right) .3 .19$ (l H. m, $\mathrm{CHNH}$ ), 4.25 (I H. d. $J=8.6 . \mathrm{CHOH}$ ), 6.99-7.02 (5 H. m. $\mathrm{ArH}):{ }^{13} \mathrm{C}$ NMR ( $\left.50 \mathrm{MHz} . \mathrm{D}_{2} \mathrm{O}-1 \mathrm{NDCl}\right)$ $\delta 14.73\left(\mathrm{CH}_{3}\right), 52.88\left(\mathrm{CHNH}_{2}\right), 74.95(\mathrm{CHOH}) .127 .11$, 129.14. 139.40 (Ar-C): [a] 30.29 (c 1.29. EtOH) $\left\{\right.$ lit. $^{96}$ $\left.[\alpha]_{\mathrm{R}}^{30}=-32.6(c 3.5 . \mathrm{EtOH}), 1 R .2 R\right\} ;$ For $(1 R, 2 R)-\mathbf{2} \cdot \mathrm{HCl}$ : $[\alpha]_{\mathrm{D}}^{30}=-37.67\left(c 1.02 . \mathrm{H}_{2} \mathrm{O}\right)\left\{\right.$ lit. $\left.^{15}[\alpha]_{D}=-38.9(c) 1.0 . \mathrm{H}_{2} \mathrm{O}\right)$, $1 R .2 R$.$\} .$

Preparation of (S)-2-amino-1-phenylpropanone hydrochloride [(S)-cathinone $\cdot \mathrm{HCl}](S)-3 \cdot \mathbf{H C l}$ from $8 \mathrm{a}$.

According to the literature procedure. ${ }^{y_{4}}$ a solution of $8 \mathrm{a}$ (1 mumol) with $96 \%$ ee was added to a suspension of PCC (1.5 
mmol) in $\mathrm{CH}_{2} \mathrm{Cl}_{2}(+\mathrm{mL})$. The mixture was stirred at room temperature for $2 \mathrm{~h}$. After ether $(10 \mathrm{~mL})$ was added, the mixture was filtered on a celite short columnn. The column was washed with ether $(3 \times 10 \mathrm{~mL})$. The combined filtrate was dried over anhydrous $\mathrm{MgSO}_{4}$. filtered and concentrated. Crude product was further purified by a flash colunn chromatography on silica gel (230-400 mesh) using ethyl acetate/hexane (1/2) as eluent to give (S)-2-N-Boc-amino-1phenylpropanone $7 \mathrm{a}$ in $82 \%$ yield: $R_{\mathrm{f}} 0.25$ : white solid: $\mathrm{mp}$ $68-70^{\circ} \mathrm{C}\left(\mathrm{lit}^{\mathrm{g}_{\mathrm{a}}} 70-72^{\circ} \mathrm{C}\right) ;[\alpha]_{\mathrm{D}}^{20}-2.25\left(c 1.15 . \mathrm{CHCl}_{3}\right)\left\{\right.$ lit $^{y_{\alpha}}$ $[\alpha]_{J}^{5} 2\left(c 0.03, \mathrm{CHCl}_{3}\right), S,>95 \%$ ee $)$ : HPLC analysis $[i s o-$ $\mathrm{PrOH} /$ hexane: $1 / 9$; flow rate: $0.5 \mathrm{~cm}^{3} / \mathrm{min}$; detector: $254 \mathrm{~nm}$ : $t_{\mathrm{R}}(2 \mathrm{~S}) 9.84 \mathrm{~min}$ and $t_{\mathrm{R}}(2 R) 13.23 \mathrm{~min}$ ] showed it to be $96 \%$ ee with (S)-configuration: All of IR, ${ }^{1} \mathrm{H}$ and ${ }^{13} \mathrm{C}$ NMR spectra of this compound were identical with those of its $(R)$ isomer. A solution of $(S)-7 \mathrm{a}(\mathrm{I}$ munol $)$ with $96 \%$ ee in EtOAc $\left(4 \mathrm{~cm}^{3}\right)$ was treated with $3 \mathrm{~N} \mathrm{HCl}$ solution at room temperature for $1 \mathrm{~h}$. The misture was concentrated and the residue was recrystallized from iso-PrOH-Et $2 \mathrm{O}$ to give $(S)$ $3 \cdot \mathrm{HCl}$ in $89 \%$ yield: white solid; mp $179-181^{\circ} \mathrm{C}$ (lit ${ }^{19} 180$ $\left.182^{\circ} \mathrm{C}\right) ; \mathrm{IR}\left(\mathrm{KBr} / \mathrm{cm}^{-1}\right) 3+42.3005 .1688 .1497 .{ }^{1} \mathrm{H}$ NMR $\left(400 \mathrm{MHz}, \mathrm{CD}_{3} \mathrm{OD}\right) \delta 1.57\left(3 \mathrm{H} . \mathrm{d}, J=6.6, \mathrm{CH}_{3}\right), 5.14(\mathrm{l} \mathrm{H}$. q. $\left.J=6.7, \mathrm{CHNH}_{2}\right) .7 .58-7.61(2 \mathrm{H} . \mathrm{m}), 7.73(\mathrm{l} \mathrm{H}, \mathrm{m}) .8 .06$ $(2 \mathrm{H}, \mathrm{d}, J 7.5)(\mathrm{ArH}) ;{ }^{13} \mathrm{C}$ NMR $\left(100 \mathrm{MHz}, \mathrm{CDCl}_{3}\right) \delta 18.20$ $\left(\mathrm{CH}_{3}\right), 53.33\left(\mathrm{CHNH}_{2}\right) .130 .37 .130 .76,134.61 .136 .22(\mathrm{Ar}-$ C). 197.68 (PhCO): These NMR spectra data were identical with those of literature values. $^{\text {9.a. }}[\alpha]_{\mathrm{D}}^{30}=.45 .2$ (c 1.20 . $\left.\mathrm{H}_{2} \mathrm{O}\right) .96 \%$ ee $\left\{\mathrm{lit}^{\gamma_{\mathrm{a}}}[\alpha]_{\mathrm{J}} \mathrm{s}=.48\left(\mathrm{c} 0.02, \mathrm{H}_{2} \mathrm{O}\right),>95 \%\right.$ ee $\}$.

Acknowledgment. This study was supported by Hallym University Research Fund (HRF-2002-32).

\section{References}

1. Seyden-Penne. J. Chiral Aturitiaries and Ligands in Asymmetric Symthesis: Tohn Wiley \& Sons: New York. 1995.

2. For reviews, see: (a) Bergmeier. S. C. Tetrahtedron 2000. 56. 25612576. (b) Ager. D. J.: Prakash. I.: Schaad. D. R. Chem. Rev 1996. 96. $835-875$.

3. For recent papers. see: (a) Mevers. A. G.: Yang B. H. Org Symh 1999, 77. 22-28 and references cited therein. (b) Abiko, A. Org. Swhi 2002, 79, 116-124 and references cited therein. (c) Kurosu. M.: Lorca. M. J. Org. Chem. 2001. 66. 1205-1209. (d) Andrus. M. B.: Soma Sekhar. B. B. V.: Turner. T. M: Meredith. E. L. Tetrohedron Lett. 2001. 12.7197-7201. (e) Vicario. J. L.: Badia. D.: Carrillo. L. Org. Lett 2001 3, 773-776. (f) Nagula, G.: Huber. V. I.: Lum. C.: Goodman, B. A. Org. Lett. 2000, 2, 3527-3529. (g) Mevers. A. G.: Gleason. I. L. Org. Symth. 1998, 76, $57-58$ and references cited therein (h) de Sousa. S. E.: O Brien. P.: Pilgram. C. D. Tetrahedron 2002. 58.4643-4654. (i) Brookes. P. C.: Milne, D. J: Murphy. P. J.: Spolaore. B. Tetrahedron 2002. 58. 4675 4680. (j) Colman. B.: de Sosa. S. E.: O Brien. P.: Towers, T. D.: Waston. W. Tetrohedron: Asymmetre 1999, 10, 4175-4182. (k) Fontaine. E: Namane, C.: Menevrol. J:Geslin, M.: Serva. L.: Roussey. E.: Tissandie. S.: Mattouh. M.: Roger. P. Tetrahedron:
Astntmetry 2001. 12. 2185-2189. (1) Sandee. A. J.: Petra. D. G. I.: Reek. T. N. H.: Kamer. P. C. J.: van Leeuwen. P. W. N. M. Chent. Eur. J. 2001. 7. 1202-1208. (m) Itsuno. S.: Watanabe. K.: EIShehawy. A. A. Adv. Symth \& Catal 2001. 343. 89-94. (n1) Frantz. D. E.: Fassler. R.: Carreira, E. M. J. Am. Chem. Soc. 2000. 122. 1806-1807. (o) Li, Z.; Upadhyary, V.: DeCamp. A. E.: Di Michele. L.: Reider. P. J. Symhesis 1999, 1453-1458. (p) Tan, L: Chen. C.y.: Tillyer. R. D.: Grabowski. E. T. I. Angew. Chent Int. Ed $1999.38 .711-713$.

4. Kamata. K.: Agata. I.: Meyers. A. I. J. Org. Chem. 1998. 63. 3113-3116.

5. Agami. C. Couty. F.: Evano. G. Tetahedron Asymmeny 2000. 11. $4639-4643$.

6. Vant. I. N.: De Kimpe. N. Tetrahederon 2000. 56. 7299-7304.

7. Boland. N. A.: Casey: M.: Hynes. S. J:: Matthews. W: Smyth. M. P. J. Org. Chem 2002. 67.3919-3922.

8. (a) Berrang, B. D.: Lewin, A. H. Carroll. F. I. J. Org Chem. 1982. 47. 2643-2647. (b) Jarowsti, C.: Hartung. W. H. J. Org. Chem. 19+3, $8,564-571$.

9. (a) Besse. P.: Veschambre. H.: Dickmant. M.: Chênevert. R. J. Org. Chent 1994. 59. 8288-8291. (b) Moran. P. J. S.: Rodrigues. T. A R.: Joekes. I.: Brenelli. E. C. S.: Leite. R. A. Biocatalysis 1994.9. 321-328.

10. Brandes, B. D.: Jacobsen, E. N. Synlett 2001. 1013-1015.

11. Oppolzer, W.: Tamura, O: Sundarababu. G.: Signer. M. J. Am. Chent. Soc. 1992. $11+.5900-5902$

12. Kreutz. O. C.: Morant. P. T. S.: Rodrigues. T. A. R. Tetrahedhon: Asummetry 1997. 8. 2649-2653.

13. (a) Reddy; G. V: Rao, G. V: Sreevanı. V: Iyengar, D. S Tetrahedron Lett. 2000, $11,953-954$. (b) Gusselin, F.: Betsbrugge. J. V.: Hatam. M.: Lubell. W. J. Org. Chem. 1999, 64. 2489-2493.

14. Effenberger. F.: Gutterer. B.: Jager. T. Tetrahedon: Astmmetn 1997. 8. 459-467.

15. Claremon. D. A.: Lumma. P. K.: Phillips. B. T. J. Am. Chem. Soc. 1986. $108,8265-8266$.

16. For reviews, see: (a) Seyden-Penne, Reductions by the Ahminoand bonolndrides in Organic Sinthesis; Wiely-VCH. Ine: New York. 1997, (b) Ramachandran. P. V.: Brown. H. C. Reductions in Organic Smthesis: Abdel-Magid. A. F.. Ed.: ACS Symposium Series 641: American Chemical Society: Washington1. DC. 1996: pp 84-97. (c) Cho. B. T.; Chun. Y. S. Organobornes for Symtheses: Ramachandran, P. V.. Brown, H. C., Eds.: ACS Symposium Series 783, American Chemical Society: Washington. DC, 2001: pp 122135. (d) Itsuno. S. Org. React 1998. 52. 395-576: (e) Itsuno. S. Conprehensive Asmmetric Catahsts. Tacobsetr. E. N. Ptaltz. A. Yamamoto. H.. Eds.: Springer-Verlag: New York. 1999: Vol. 3. pp 289-315. (1) Corey. E. J.; Helal C. J. Angew. Chem, Int Ed Engl. 1998. 37. 1986-2012. (h) Daverio, P.: Zanda, M. Tetrahedron: Astntwetry 2001. 12.2225-2259.

17. Cho. B. T. Aldrichint deta 2002. 35.3-16.

18. Masamune. S.: Choy. W.: Petersen. J. S.: Sita. L. R. Angew. Chent. Int. Ed. 1985. 24. 1-30 and reterences cited therein.

19. Greene. D. W. Wuts, P. G. M. Protective Groups in Organic Synthesis, $3^{\text {rd }}$ ed; Joln Wiley \& Sons, Inc: New York, 1999 and references cited therein.

20. Eliel. E. L. Aswmmetric Symesis: Morrison. T. D.. Ed.: Academic Press: New York. 1983: Vol. 2. chapter 2 and references cited therein.

21. Rogic. M. M; Ramachandran. P. V; Zinnen. H; Brown, K. D.; Zheng. M. Tetrahedron: Astmmety 1997. 8. 1287-303 and references cited therein.

22. Lamant. M.: Guignard. A. Het. Chint. Acta 1987. 70. 1279-1285. 